NASA/TM-2008-214915

ARL-TR-4367
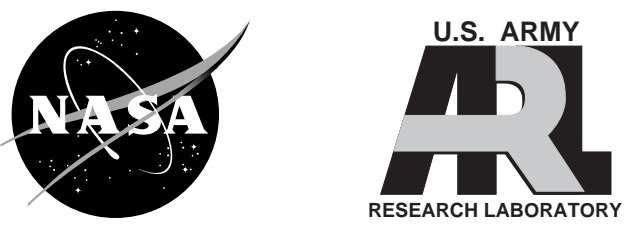

\title{
Thermal Barrier and Protective Coatings to Improve the Durability of a Combustor Under a Pulse Detonation Engine Environment
}

Louis J. Ghosn

Ohio Aerospace Institute, Brook Park, Ohio

Dongming Zhu

U.S. Army Research Laboratory, Glenn Research Center, Cleveland, Ohio 


\section{NASA STI Program . . . in Profile}

Since its founding, NASA has been dedicated to the advancement of aeronautics and space science. The NASA Scientific and Technical Information (STI) program plays a key part in helping NASA maintain this important role.

The NASA STI Program operates under the auspices of the Agency Chief Information Officer. It collects, organizes, provides for archiving, and disseminates NASA's STI. The NASA STI program provides access to the NASA Aeronautics and Space Database and its public interface, the NASA Technical Reports Server, thus providing one of the largest collections of aeronautical and space science STI in the world. Results are published in both non-NASA channels and by NASA in the NASA STI Report Series, which includes the following report types:

- TECHNICAL PUBLICATION. Reports of completed research or a major significant phase of research that present the results of NASA programs and include extensive data or theoretical analysis. Includes compilations of significant scientific and technical data and information deemed to be of continuing reference value. NASA counterpart of peer-reviewed formal professional papers but has less stringent limitations on manuscript length and extent of graphic presentations.

- TECHNICAL MEMORANDUM. Scientific and technical findings that are preliminary or of specialized interest, e.g., quick release reports, working papers, and bibliographies that contain minimal annotation. Does not contain extensive analysis.

- CONTRACTOR REPORT. Scientific and technical findings by NASA-sponsored contractors and grantees.
- CONFERENCE PUBLICATION. Collected papers from scientific and technical conferences, symposia, seminars, or other meetings sponsored or cosponsored by NASA.

- SPECIAL PUBLICATION. Scientific, technical, or historical information from NASA programs, projects, and missions, often concerned with subjects having substantial public interest.

- TECHNICAL TRANSLATION. Englishlanguage translations of foreign scientific and technical material pertinent to NASA's mission.

Specialized services also include creating custom thesauri, building customized databases, organizing and publishing research results.

For more information about the NASA STI program, see the following:

- Access the NASA STI program home page at http://www.sti.nasa.gov

- E-mail your question via the Internet to help@sti.nasa.gov

- Fax your question to the NASA STI Help Desk at 301-621-0134

- Telephone the NASA STI Help Desk at 301-621-0390

- Write to: NASA Center for AeroSpace Information (CASI) 7115 Standard Drive Hanover, MD 21076-1320 
NASA/TM-2008-214915

ARL-TR-4367
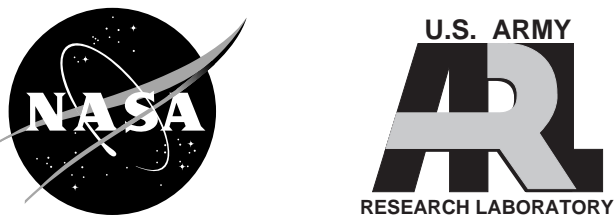

AIAA-2007-2070

\section{Thermal Barrier and Protective Coatings to Improve the Durability of a Combustor Under a Pulse Detonation Engine Environment}

Louis J. Ghosn

Ohio Aerospace Institute, Brook Park, Ohio

Dongming Zhu

U.S. Army Research Laboratory, Glenn Research Center, Cleveland, Ohio

Prepared for the

48th Structures, Structural Dynamics, and Materials Conference cosponsored by the AIAA, ASME, ASCE, AHS, and ASC

Waikiki, Hawaii, April 23-26, 2007

National Aeronautics and

Space Administration

Glenn Research Center

Cleveland, Ohio 44135 
This work was sponsored by the Fundamental Aeronautics Program at the NASA Glenn Research Center.

Level of Review: This material has been technically reviewed by technical management.

Available from

NASA Center for Aerospace Information 7115 Standard Drive

Hanover, MD 21076-1320
National Technical Information Service 5285 Port Royal Road Springfield, VA 22161

Available electronically at http://gltrs.grc.nasa.gov 


\title{
Thermal Barrier and Protective Coatings to Improve the Durability of a Combustor Under a Pulse Detonation Engine Environment
}

\author{
Louis J. Ghosn \\ Ohio Aerospace Institute \\ Brook Park, Ohio 44142 \\ Dongming Zhu \\ U.S. Army Research Laboratory \\ Glenn Research Center \\ Cleveland, Ohio 44135
}

\begin{abstract}
Pulse detonation engine (PDE) concepts are receiving increasing attention for future aeronautic propulsion applications, due to their potential thermodynamic cycle efficiency and higher thrust to density ratio that lead to the decrease in fuel consumption. But the resulting high gas temperature and pressure fluctuation distributions at high frequency generated with every detonation are viewed to be detrimental to the combustor liner material. Experimental studies on a typical metal combustion material exposed to a laser simulated pulse heating showed extensive surface cracking. Coating of the combustor materials with low thermal conductivity ceramics is shown to protect the metal substrate, reduce the thermal stresses, and hence increase the durability of the PDE combustor liner material. Furthermore, the temperature fluctuation and depth of penetration is observed to decrease with increasing the detonation frequency. A crack propagation rate in the coating is deduced by monitoring the variation of the coating apparent thermal conductivity with time that can be utilized as a health monitoring technique for the coating system under a rapid fluctuating heat flux.
\end{abstract}

\section{Introduction}

The pulse detonation engine (PDE) concept has been studied at NASA Glenn Research Center to assess the feasibility of creating a hybrid gas turbine engine in which the constant pressure combustor is replaced by a detonative combustor. In the hybrid PDE, a detonative combustor would be burned in a cyclic detonation process at several hundred cycles per second and achieve near constant volume burning (ref. 1). The constant volume burning process is more efficient thermodynamically than constant pressure combustion at the current operating pressures of aero turbine engines (refs. 2 and 3). The fuel in a detonative combustor would be burned in a cyclic detonation process at several hundred cycles per second (refs. 3 and 4). In a PDE process, a mixture of fuel and air fills the detonation tube, and a spark is ignited to initiate the detonation at the end tube. When a detonation is initiated, a sharp pressure and temperature peaks are observed for a short duration on the order of 1/10 ms, followed by a sharp decrease to a plateau region of constant values for duration of several milliseconds prior to a final decay to the lower fuel mixture fill pressure. As the burned gases exhaust the device, a new fuel-air mixture is supplied to initiate a new cycle. The process is repeated at a rate sufficient to provide the enthalpy required by the turbine to drive the cycle. However, for the success of a hybrid PDE concept, the material of choice should be capable of enduring the severe pulsing environment created by the repetitive detonations (ref. 5).

The design of a long life pulse detonation combustor is essential to the successful implementation of detonative combustor technology in future engines. Preliminary studies of materials exposed to high cycle pulsating thermal loads using laser heating have resulted in the induction of significant surface cracking (refs. 5 and 6) due to a creep/fatigue interaction that is expected to reduce the life of the component. Various techniques such as film cooling (refs. 7 and 8), aspiration cooling (ref. 9), and thermal barrier coating (ref. 10) are attractive techniques that have been successfully used for many years in steady constant pressure combustors to increase the durability of hot components such as turbine blades and combustor liners. This paper summarizes a numerical and experimental effort to demonstrate the feasibility of a thermal barrier coating concept to protect a typical combustor material, Haynes ${ }^{\circledR} 188$ (Kokomo, IN), and Nickel base alloys, in the presence of repetitive pulsed heat flux resulting from high cycle detonation waves.

In previous studies (refs. 5 and 6), a high cycle thermal fatigue test rig incorporating a $\mathrm{CO}_{2}$ laser was used to evaluate the performance of Haynes ${ }^{\circledR}$ 188. The material is a commercially available cobalt-nickel-chromium- 
(a)

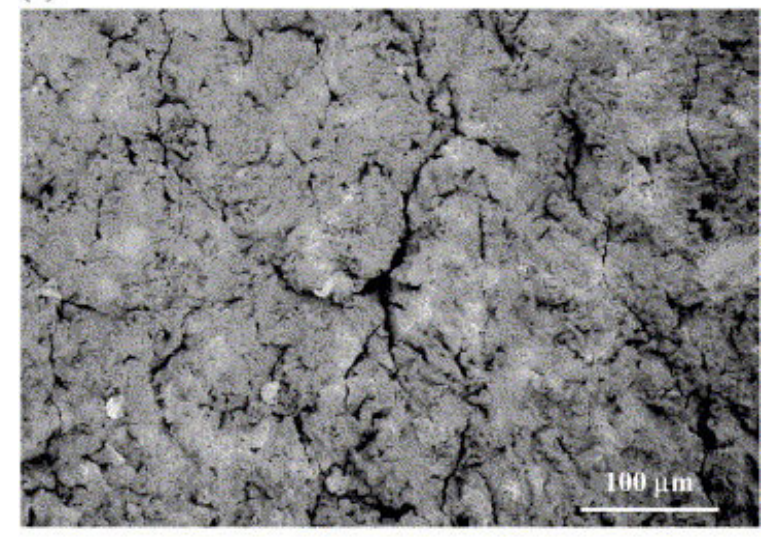

(b)

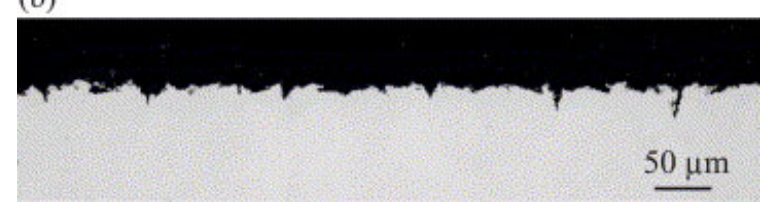

Figure 1.-Surface cracking on Haynes-188 after exposure to a fluctuating heat flux using a laser system at $30 \mathrm{~Hz}$ with a spike exposure of $10 \mathrm{~ms}$, (a) top view, and (b) cross-sectional view.

tungsten alloy. It was chosen due to its high temperature strength and good oxidation resistance up to $1100{ }^{\circ} \mathrm{C}$ $\left(2000{ }^{\circ} \mathrm{F}\right)$. It is currently used in commercial and military gas turbine engines for components such as combustion cans, transition ducts and after-burner components (ref. 11).

The cyclic thermal fatigue of Haynes 188 was investigated under a $30 \mathrm{~Hz}$ pulsed laser exposure. A total of $33 \mathrm{~ms}$ pulse period included a $0.2 \mathrm{~ms}$ high temperature spike and a $10 \mathrm{~ms}$ plateau to simulate the detonative heat loads. The specimens were tested with the high frequency laser pulsed at an average surface temperature of $800{ }^{\circ} \mathrm{C}$ and a backside temperature of $650{ }^{\circ} \mathrm{C}$. About $40{ }^{\circ} \mathrm{C}$ temperature fluctuations resulting from the pulse caused significant thermal cyclic stresses to form an oxide scale along the exposed surface, see figure 1 . The oxide scale induced extensive surface cracking that penetrated the substrate under repeated pulsed heating, as seen in figure 2. The micrographs of figure 2 indicate that oxidation and creep-fatigue interactions at the oxide scale/alloy interface was a damaging mechanism for surface crack initiation and propagation under simulated PDE heating conditions. The extent of the damage is a clear indication to the necessity of a thermal protection system for PDE combustor materials. The protection system studied here is a ceramic coating acting as a thermal barrier with an oxidation resistance bond coat. This system has been applied successfully in hot sections of standard constant pressure combustion engines (ref. 10), but not applied under high speed pulsed heat flux conditions. This paper investigates the feasibility for improving the durability of coated combustor liner materials such as Haynes 188 and Nickel-based alloy specimens under various simulated pulsed detonation scenarios for future applications in a pulse denotation engine environment. The variation of the coating apparent thermal conductivity with time is utilized as a health monitoring technique for the coating system under a rapid fluctuating heat flux assuming a coating cracking pattern.

\section{Analytical Modeling of Haynes-188 Under a High Speed Pulsed Heat Flux}

Finite element studies are conducted using ABAQUS standard (ref. 12) to determine the temperature and resulting thermal stress distributions on coated and uncoated circular samples of Haynes 188 substrate. The samples are about $25.4 \mathrm{~mm}$ in diameter and $1.575 \mathrm{~mm}$ thick. The coating system is a baseline system with a $0.127 \mathrm{~mm}$ thick $\mathrm{Ni}-17$ (wt.\%)Cr-6\%Al-0.5\% ( NiCrAlY) bond coat and a $0.381 \mathrm{~mm}$ thick $\mathrm{ZrO}_{2}-8 \mathrm{wt} \% \mathrm{Y}_{2} \mathrm{O}_{3}$ (YSZ) ceramic top coat. Table 1 compares the material thermal and mechanical properties of Haynes 188, NiCrAlY and YSZ, at temperature, as well as a Nickel base-alloy. The simulated heat flux applied to the hot face is a three stage heat flux, with a high 
(a)

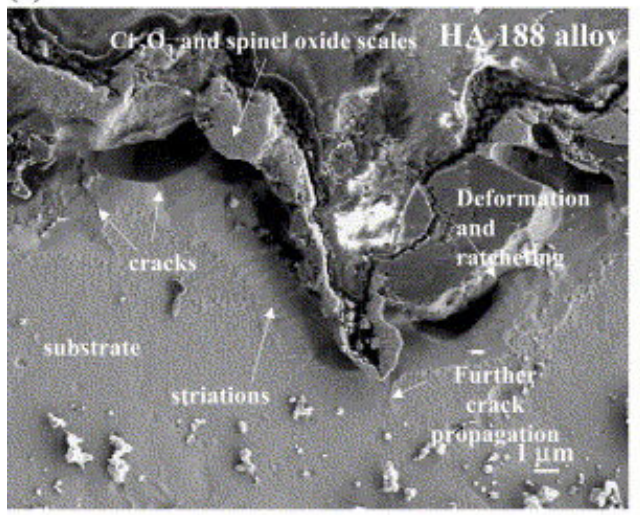

(c)

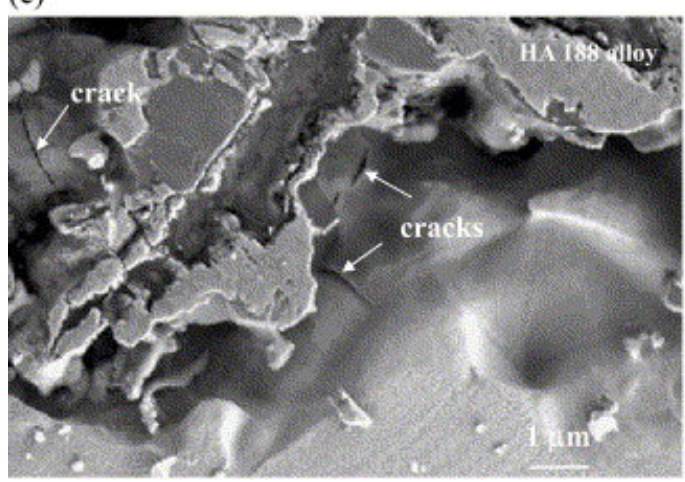

(b)

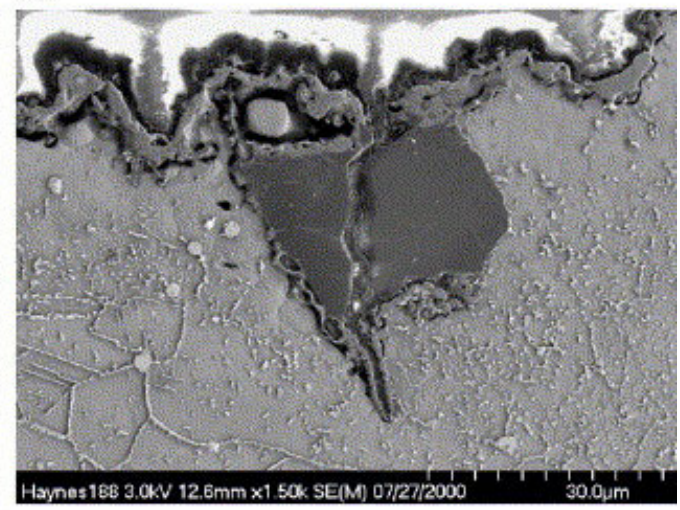

(d)

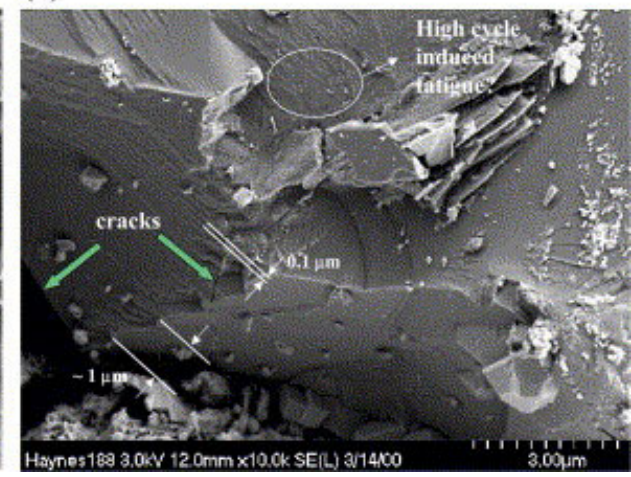

Figure 2.-Micrographs showing significant specimen oxidation, creep deformation and fatigue in the alloy substrate near the oxide scale/alloy interfaces for a Haynes 188 alloy specimen after the laser thermal cyclic testing. (a) and (b) Cross-sections of the specimen showing a surface crack penetrating into the alloy and associated oxide scale-alloy substrate fatigue striation and crack initiation. (c) and (d) Microcracks and fatigue striations initiated in the alloy at the alloy/oxide interface under the surface cyclic thermal stresses.

spike of $1200 \mathrm{~W} / \mathrm{cm}^{2}$ for $0.2 \mathrm{~ms}$, followed by a $170 \mathrm{~W} / \mathrm{cm}^{2}$ plateau for $9.8 \mathrm{~ms}$, and finally followed by a cooling flux of $10 \mathrm{~W} / \mathrm{cm}^{2}$ for a $10 \mathrm{~ms}$ duration, simulating the cool down of the PDE combustor liner by the filling effect of the new fuel/air mixture. A back cooling boundary condition is imposed to cool down the sample with a $23{ }^{\circ} \mathrm{C}$ air with a corresponding $0.152 \mathrm{~W} / \mathrm{cm}^{2}-{ }^{\circ} \mathrm{C}$ convective film coefficient, to maintain the substrate back face temperature at $615{ }^{\circ} \mathrm{C}$. The time average heat load is equal to $90 \mathrm{~W} / \mathrm{cm}^{2}$ with a $50 \mathrm{~Hz}$ frequency. The surface temperature distributions as a function of time are shown in figure 3 (a) and (b) for uncoated and coated specimens. For the uncoated specimen, the maximum Haynes 188 top face temperature swings from 706 to $676^{\circ} \mathrm{C}$ with each pulse, while the back face temperature remains at around $615^{\circ} \mathrm{C}$. With the application of the coating system, the substrate hot side temperature is maintained more or less around $680{ }^{\circ} \mathrm{C}$ with a less than $2{ }^{\circ} \mathrm{C}$ temperature swing. On the other hand the temperature of the hot surface of the protective coating is now increased to a maximum temperature of $1084{ }^{\circ} \mathrm{C}$ and a minimum temperature of $923{ }^{\circ} \mathrm{C}$ with each pulse, due to the low thermal conductivity of the top ceramic top coating. Although the temperature variation in the top coat is increased, it is accomplishing the role of shielding the substrate from the pulsed heat flux. A closer look at the temperature variation with depth reveals that the depth of the temperature swings is limited to be within the top coat layer only with a depth of $0.111 \mathrm{~mm}$ as compared to a $0.360 \mathrm{~mm}$ for the uncoated specimen as seen in figure 4 . The resulting thermal induced stresses are then calculated for the coated and uncoated specimens as a function of the distance from the cooled substrate back face for various time increments and shown in figure 5. For the uncoated specimen, the maximum stress is on the hot face of the specimen with a maximum hoop stress of $31 \mathrm{MPa}$ that decrease to $-114 \mathrm{MPa}$ for every cycle resulting in a stress range of $144 \mathrm{MPa}$. For the coated substrate, the maximum temperature is a negative $8 \mathrm{MPa}$ with a minimum stress of -116 MPa for a resulting compressive/compressive hoop stress range of $108 \mathrm{MPa}$. The decrease of the stress range with the application of the coating demonstrates clearly the benefit of the coating system in protecting the substrate. 
Table 1.-Assumed Thermal and Mechanical Material Properties for the Coating and Substrates.

\begin{tabular}{|c|c|c|c|c|c|c|c|}
\hline & Temperature & Density & $\begin{array}{l}\text { Elastic } \\
\text { Modulus }\end{array}$ & $\begin{array}{l}\text { Poisson's } \\
\text { Ratio }\end{array}$ & $\begin{array}{c}\text { Thermal } \\
\text { Expansion } \\
\text { Coefficient }\end{array}$ & $\begin{array}{c}\text { Thermal } \\
\text { Conductivity }\end{array}$ & $\begin{array}{c}\text { Specific } \\
\text { Heat }\end{array}$ \\
\hline & $\mathrm{C}$ & $\mathrm{g} / \mathrm{cc}$ & Gpa & & $\mathrm{x} 10^{-6} 1 / \mathrm{C}$ & $\mathrm{W} / \mathrm{m}-\mathrm{C}$ & $\mathrm{KJ} / \mathrm{Kg}-\mathrm{C}$ \\
\hline \multirow{3}{*}{ Haynes-188 } & RT & \multirow{3}{*}{7.71} & 23.2 & 0.30 & 11.9 & 10.4 & 0.403 \\
\hline & 600 & & 18.4 & 0.30 & 15.8 & 21.1 & 0.523 \\
\hline & 900 & & 16.1 & 0.30 & 17.9 & 25.5 & 0.573 \\
\hline \multirow{3}{*}{ Ni-base alloy } & $\mathrm{RT}$ & \multirow{3}{*}{8.19} & 21.3 & 0.30 & 12.2 & 10.7 & 0.600 \\
\hline & 600 & & 18.0 & 0.30 & 15.0 & 19.0 & 0.575 \\
\hline & 900 & & 15.8 & 0.30 & 17.7 & 24.1 & 0.590 \\
\hline \multirow{3}{*}{ NiCrAIY } & RT & \multirow{3}{*}{7.71} & 20.4 & 0.25 & 15.0 & 10.5 & 0.455 \\
\hline & 600 & & 16.8 & 0.25 & 15.4 & 20.7 & 0.567 \\
\hline & 900 & & 13.5 & 0.25 & 17.5 & 29.0 & 0.750 \\
\hline YSZ & & 5.24 & 50.0 & 0.20 & 10.8 & 1.0 & 0.582 \\
\hline
\end{tabular}

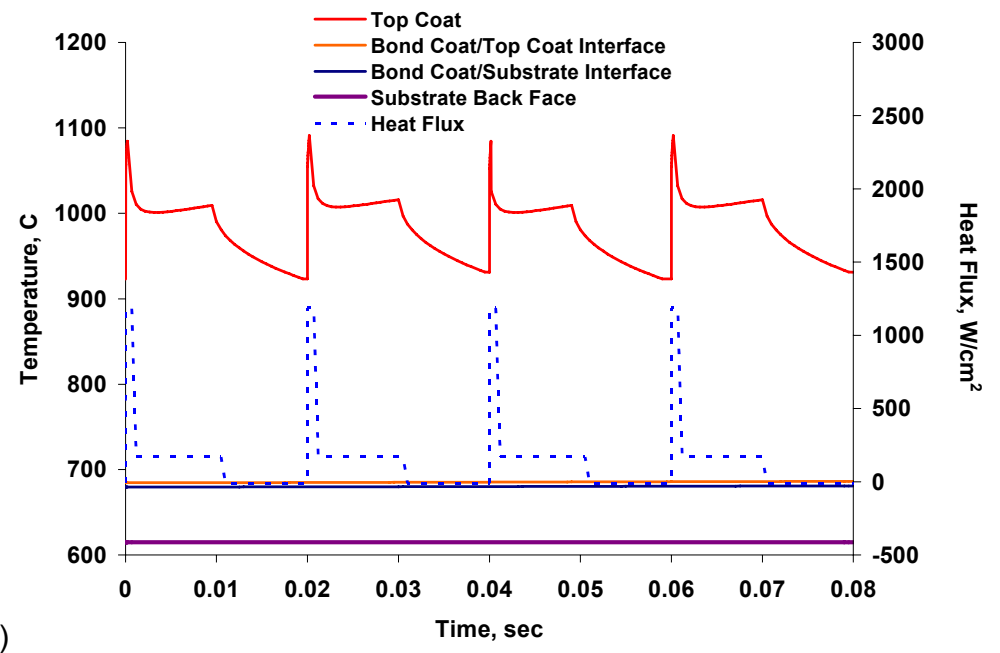

(a)

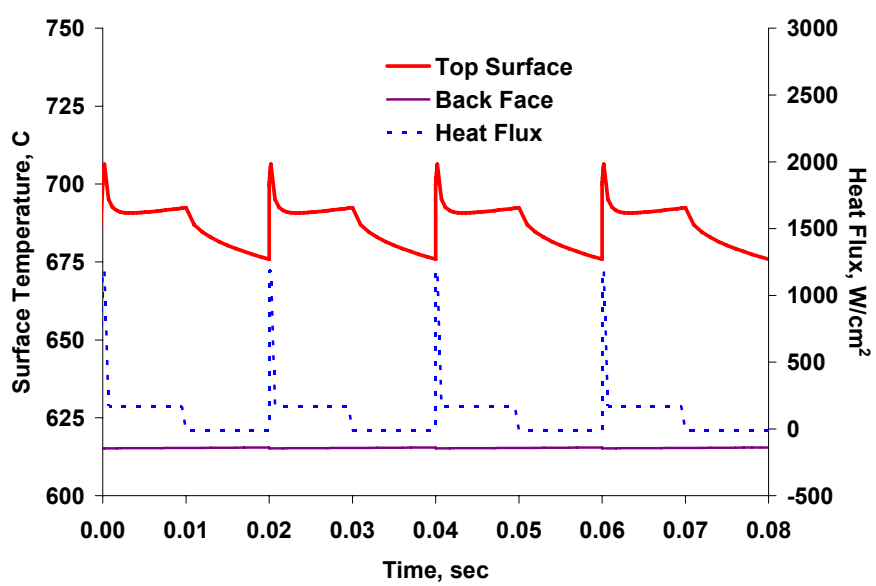

(b)

Figure 3.-Variation of temperature as a function of time under a pulsed heat flux of $50 \mathrm{~Hz}$, for a) an uncoated $1.575 \mathrm{~mm}$ thick Haynes 188 substrate and b) a coated Haynes 188 substrate with $0.127 \mathrm{~mm}$ thick NiCrAIY bond coat and a $0.381 \mathrm{~mm}$ YSZ top coat. 


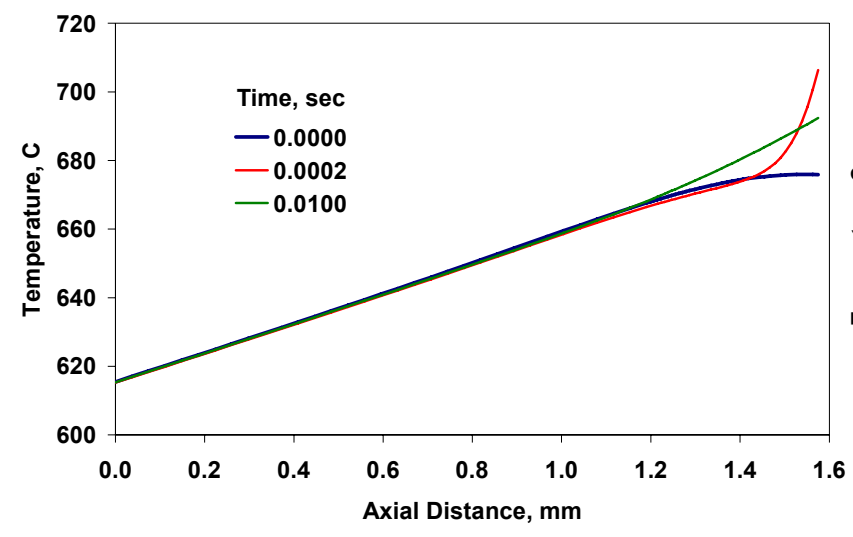

(a)

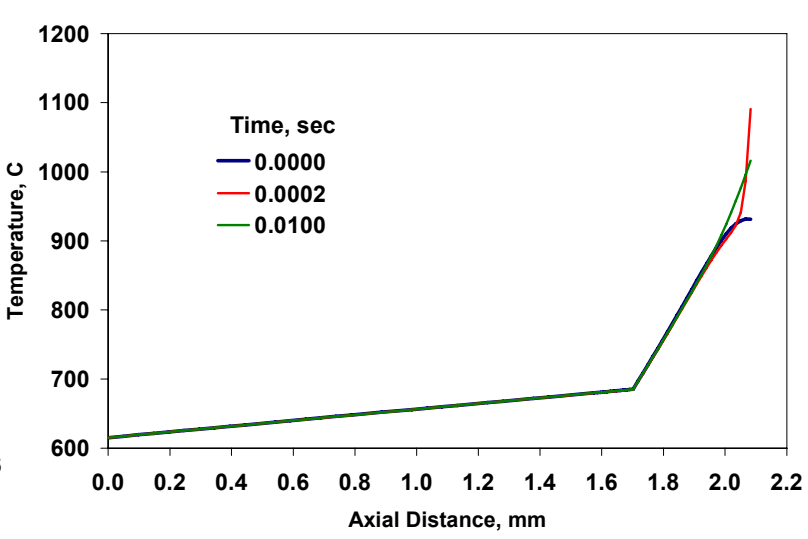

(b)

Figure 4.-Variation of the temperature as a function of depth at various time increments under a pulsed heat flux at $50 \mathrm{~Hz}$, for (a) an uncoated $1.575 \mathrm{~mm}$ thick Haynes188 substrate and (b) a coated Haynes188 substrate with $0.127 \mathrm{~mm}$ thick NiCrAIY bond coat and $0.381 \mathrm{~mm}$ YSZ top coat.

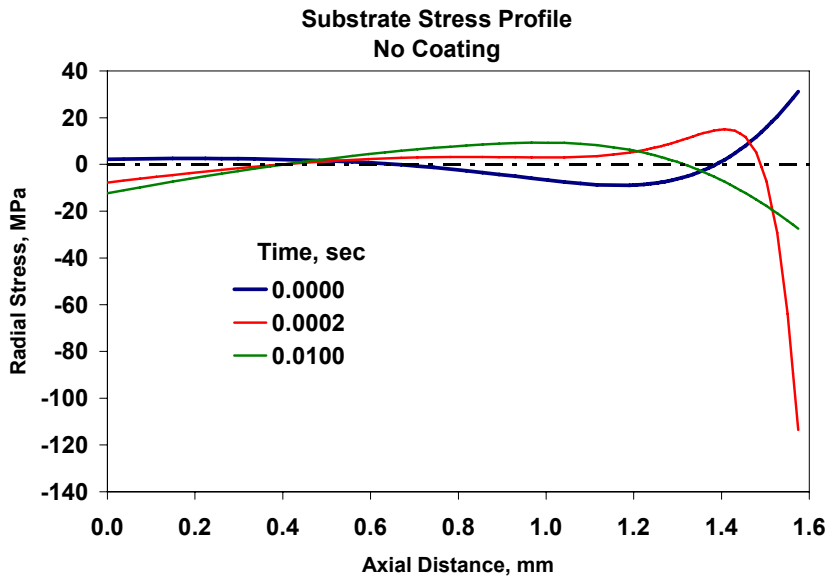

(a)

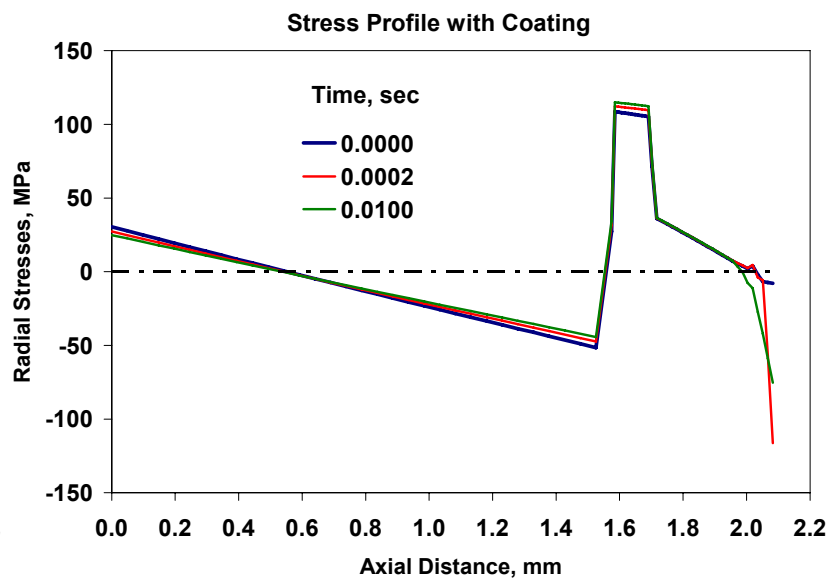

(b)

Figure 5.-Variation of the hoop stresses as a function of the distance measured from cooled substrate side at various time increments under a pulsed heat flux at $50 \mathrm{~Hz}$, for (a) an uncoated $1.575 \mathrm{~mm}$ thick Haynes 188 substrate and (b) a coated Haynes188 substrate with $0.127 \mathrm{~mm}$ thick NiCrAlY bond coat and a $0.381 \mathrm{~mm}$ YSZ top coat.

The effect of increasing the pulsed frequency from 50 to $100 \mathrm{~Hz}$ and $150 \mathrm{~Hz}$ is analyzed next assuming the same time average heat flux of $90 \mathrm{~W} / \mathrm{cm}^{2}$. The sharp spike of $1200 \mathrm{~W} / \mathrm{cm}^{2}$ for $0.2 \mathrm{~ms}$ is maintained for all three frequencies, but the plateau time and the fill time are now decreased according to the applied frequency. The plateau heat flux is maintained at $170 \mathrm{~W} / \mathrm{cm}^{2}$. But the fill cooling flux is increased with increasing frequency to maintain the back face temperature at $615^{\circ} \mathrm{C}$ and to provide for the constant time average heat load of $90 \mathrm{~W} / \mathrm{cm}^{2}$. For the $100 \mathrm{~Hz}$ simulation, the fill time is now shortened to $5 \mathrm{~ms}$ with a fill cooling flux of about $30 \mathrm{~W} / \mathrm{cm}^{2}$, and for the $150 \mathrm{~Hz}$ simulation, the fill time is now $3.33 \mathrm{~ms}$ with a fill cooling flux of $51 \mathrm{~W} / \mathrm{cm}^{2}$. Table II summarizes the finite element results showing the variation of the hot surface maximum temperature and stress with the pulsed frequency.

The maximum temperature decreases from $1190{ }^{\circ} \mathrm{C}$ at a $50 \mathrm{~Hz}$ pulsed frequency to about $1129{ }^{\circ} \mathrm{C}$ at $150 \mathrm{~Hz}$. The depth of the temperature variation is also decreased from $0.111 \mathrm{~mm}$ for the $50 \mathrm{~Hz}$ pulse to only $0.048 \mathrm{~mm}$ for the $150 \mathrm{~Hz}$. Also shown in Table II is the maximum stress and the stress ranges as they vary with the pulsed frequency. Due to the decrease in the depth of the temperature swing with increasing frequency, the hoop stress range at the surface of the top coat is also decreased from $108 \mathrm{MPa}$ at $50 \mathrm{~Hz}$ to $71 \mathrm{MPa}$ at $150 \mathrm{~Hz}$. This decrease in stress range is expected to reduce the damage accumulation in the ceramic coating and thus increase the life of the coating as seen next. 
Table II.-Temperature and hoop stress variation for uncoated and coated Haynes 188 circular specimen as a function of the pulsed frequency for a time average heat flux of $90 \mathrm{~W} / \mathrm{cm}^{2}$.

\begin{tabular}{|l|c|c|c|c|c|c|}
\hline \multicolumn{2}{|l|}{} & Tmax, C & $\boldsymbol{\Delta}$ T, C & $\begin{array}{c}\text { Depth, } \\
\boldsymbol{\mu m}\end{array}$ & $\begin{array}{c}\boldsymbol{\sigma} \text { max, } \\
\text { Mpa }\end{array}$ & $\boldsymbol{\Delta} \boldsymbol{\sigma}$, Mpa \\
\hline Uncoated & $50 \mathrm{~Hz}$ & 706 & 30 & 360 & 31 & 144 \\
\hline Coated & $50 \mathrm{~Hz}$ & 1190 & 190 & 111 & -8 & 108 \\
\hline Coated & $100 \mathrm{~Hz}$ & 1159 & 159 & 83 & -9 & 87 \\
\hline Coated & $\mathbf{1 5 0 \mathrm { Hz }}$ & 1129 & 129 & 48 & -9 & 71 \\
\hline
\end{tabular}

\section{Experiments on the Effect of Pulsed Heat Flux Frequency on Coating Durability}

To verify the effect of the pulsed frequency on the damage accumulation in the coating, pulsed laser tests are performed on a Nickel base alloy substrate with a $0.381 \mathrm{~mm}$ thick YSZ top coat and a $0.127 \mathrm{~mm}$ thick NiCrAlY bond coat. The controlled tests are performed to maintain the coating surface and coating/substrate interface temperatures at 1300 and $900^{\circ} \mathrm{C}$, respectively, with a time average heat flux $120 \mathrm{~W} / \mathrm{cm}^{2}$, with two pulsed frequencies of 50 and $100 \mathrm{~Hz}$. Pyrometers and thermocouples are used to monitor and record the temperature variation with time, at the coated hot surface, the coating/substrate interface and the cooled back substrate. Figure 6 shows the temperature variation with time of the top face, interface and back face for the two frequencies. Also shown are the normalized apparent coating thermal conductivity variation with time calculated from the measured the temperatures of the top face and the coating/substrate interface. It is postulated that the coating apparent thermal conductivity decreases with increasing coating cracking and delamination (refs. 13 and 14). As shown in figure 6, the apparent coating thermal conductivity at $50 \mathrm{~Hz}$ decreases with time as compared to the $100 \mathrm{~Hz}$. Furthermore, for the $100 \mathrm{~Hz}$ test actually the coating thermal conductivity increases slightly with time due to sintering. The sample at $50 \mathrm{~Hz}$ is cut out and inspected for damage. Figure 7 revealed a network of microcracks initiating from the surface and extending downward into the ceramic coating, after 50 hours of testing. The apparent coating thermal conductivity reduction is a direct result of the presence of arrays of multi-level cracks initiating from the surface of the coating. A calibration of the changes of the apparent coating thermal conductivity with various cracking morphologies is established next to be used as a coating health monitoring technique for damaged ceramic coating systems under rapid alternating heat fluxes.

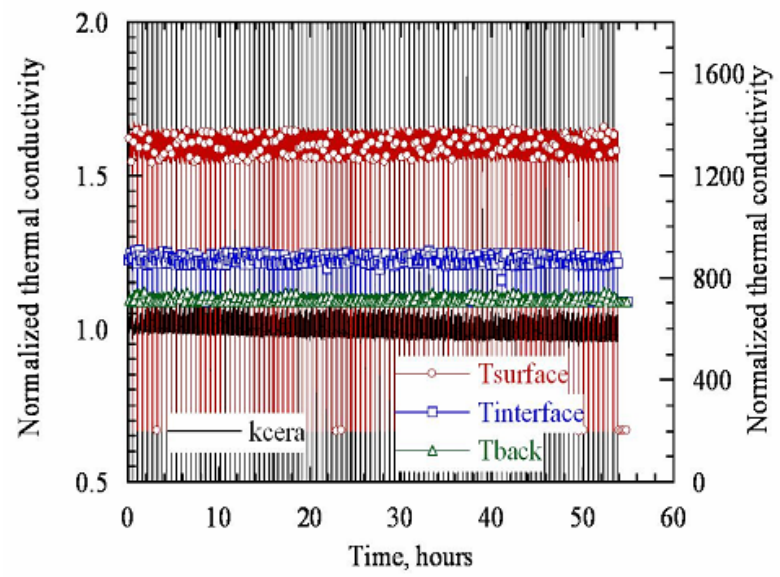

(a) $50 \mathrm{~Hz}$

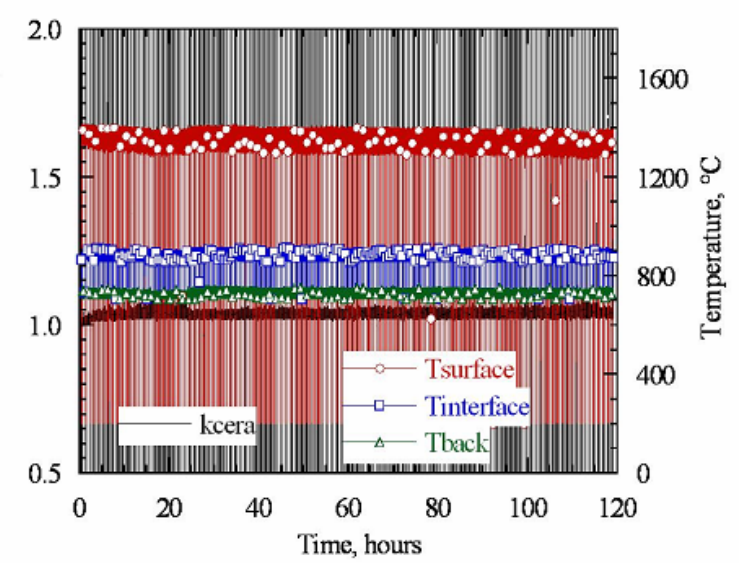

(b) $100 \mathrm{~Hz}$

Figure 6.- Variation of the temperatures and calculated apparent coating thermal conductivity with time for a $120 \mathrm{~W} / \mathrm{cm}^{2}$ time average heat flux at 50 and $100 \mathrm{~Hz}$. 


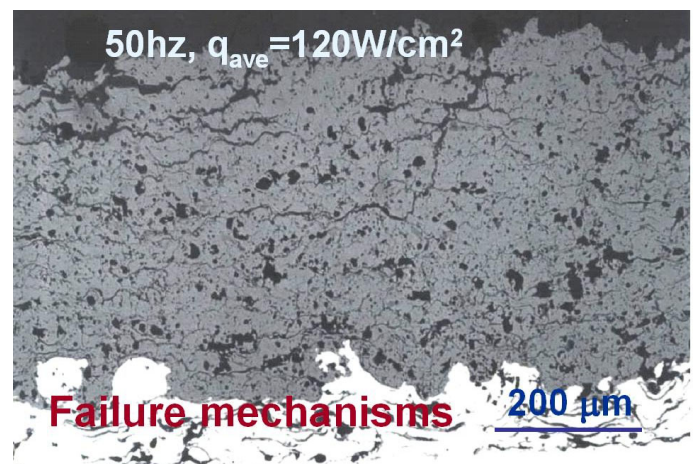

Figure 7.-Cracking morphology for a coated Ni-base alloy with a $0.127 \mathrm{~mm}$ NiCrAlY bond coat and a $0.381 \mathrm{~mm}$ YSZ top coat.

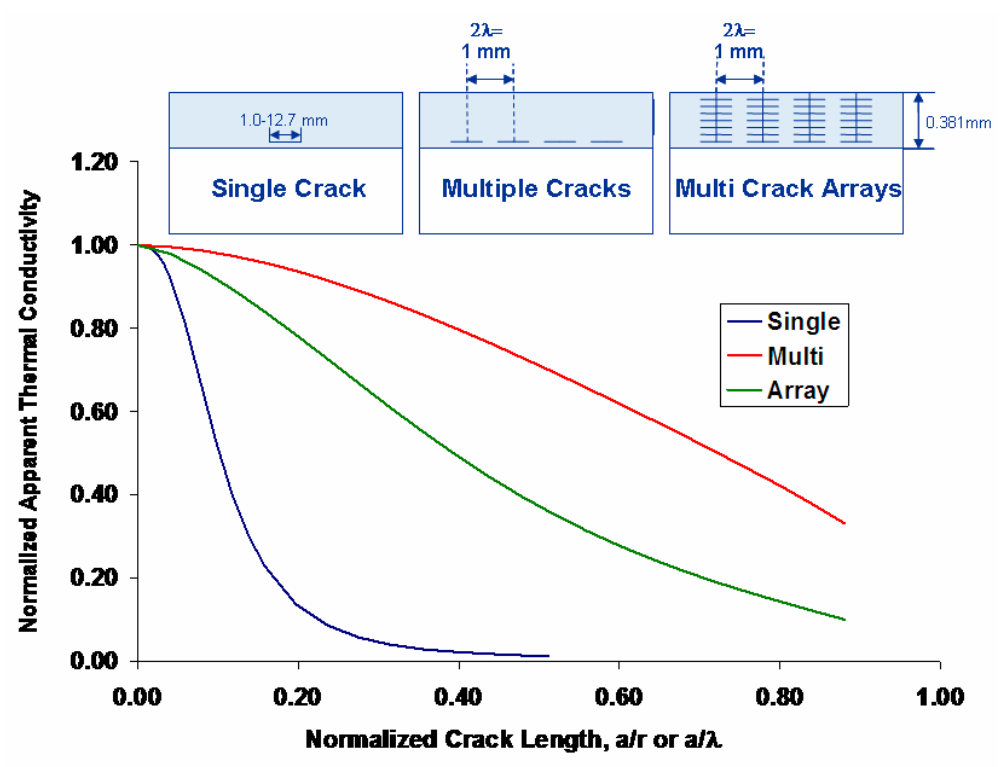

Figure 8.-Variation of the normalized apparent coating thermal conductivity with crack length for various cracking morphologies.

\section{Correlation of the Coating Cracking Morphology to the Apparent Coating Thermal Conductivity}

In this section the apparent coating thermal conductivity is correlated with the coating cracking morphology. The apparent coating thermal conductivity is calculated for three cracking morphologies as shown in figure 8:1) a single main single crack, 2) multiple cracks, and 3) arrays of multiple cracks. The finite element method is employed to calculate the temperature distribution in the coating for the various cracking patterns for a given heat flux. The distance between cracks is kept at about $1 \mathrm{~mm}$, and for the arrays of multiple cracks the axial cracking distance is about $0.05 \mathrm{~mm}$. The crack length considered in this study varies from $0.1 \mathrm{~mm}$ to about $0.9 \mathrm{~mm}$. The apparent coating thermal conductivity is simply calculated by multiplying the applied heat flux by the coating thickness and dividing by the difference between the average top face temperature and the average bond coat top coat interface temperature for various crack lengths. The variation of the apparent thermal conductivity with crack length and morphology is also shown in figure 8 . For a single crack, the thermal conductivity decays quite rapidly with crack length. For the multiple cracks, the thermal conductivity decays rather slow with increasing crack length as compared to the multi-crack arrays morphology. As shown previously the morphology observed in the $120 \mathrm{~W} / \mathrm{cm}^{2}$ pulsed heat flux, the cracking morphology can be idealized as multi-crack arrays, as seen in figure 7. Hence, if a cracking morphology is known, the crack growth rate in the coating can easily be determined as a function of the apparent coating thermal conductivity, using the calibrations of figure 8 . This methodology is applied to determine 


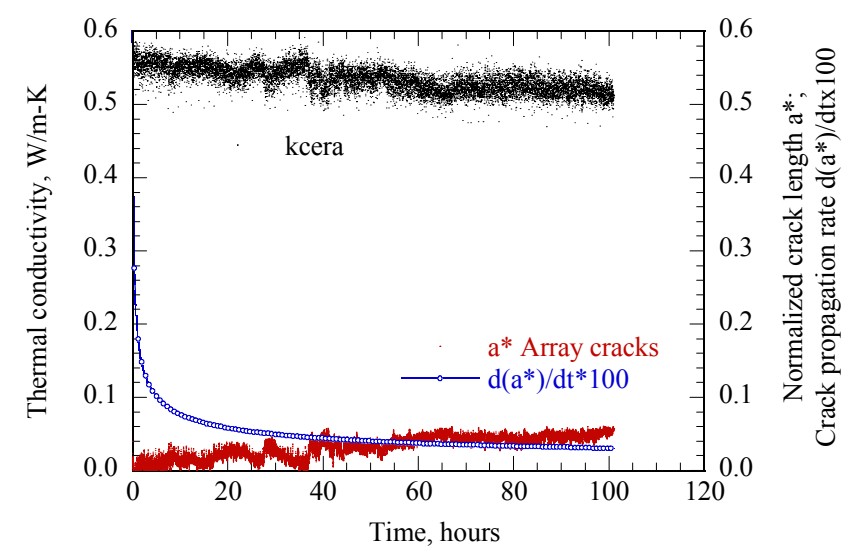

Figure 9.- Variation of the apparent coating thermal conductivity, crack length and crack growth rate as a function of time for a $0.254 \mathrm{~mm}$ low conductivity coating $\mathrm{ZrO}_{2}-\mathrm{Y}_{2} \mathrm{O}_{3}-\mathrm{Gd}_{2} \mathrm{O}_{3}-\mathrm{Yb}_{2} \mathrm{O}_{3}$ at $20 \mathrm{~Hz}$ for a time average heat flux of $68 \mathrm{~W} / \mathrm{cm}^{2}$.

the damage accumulation rate in a $0.254 \mathrm{~mm}$ thick low conductivity coating $\mathrm{ZrO}_{2}-\mathrm{Y}_{2} \mathrm{O}_{3}-\mathrm{Gd}_{2} \mathrm{O}_{3}-\mathrm{Yb}_{2} \mathrm{O}_{3}$ at $20 \mathrm{~Hz}$ for a time average heat flux of $68 \mathrm{~W} / \mathrm{cm}^{2}$ using the experimentally calculated apparent coating thermal conductivity assuming a multi-crack arrays morphology. As can be seen in figure 9 , the normalized crack length $\mathrm{a}^{*}$ was found to be approximately 0.05 after 100 hours of testing with a resulting crack growth rate, (da*)/dt, of 0.0003 per hour, assuming arrays of multi-level cracks.

\section{Conclusion}

A study was conducted to assess the durability of coated combustor liner materials under pulsed heat fluxes, simulating the heat flux profile of a PDE combustor. The coating system consisted of $0.127 \mathrm{~mm}$ thick NiCrAlY bond coat and a $0.381 \mathrm{~mm}$ thick YSZ top coat. Finite element thermal and stress analyses were performed to determine the temperature and the induced thermal stress distributions on coated and uncoated Haynes-188 substrate under a $50 \mathrm{~Hz}$ pulsed heat fluxes, simulating the PDE heat flux waves. The simulated pulsed heat flux considered had a spike of $1200 \mathrm{~W} / \mathrm{cm}^{2}$ for $0.2 \mathrm{~ms}$, followed by a plateau at $170 \mathrm{~W} / \mathrm{cm}^{2}$ for $9.8 \mathrm{~ms}$ and finally heat is taken away from the sample with cooling flux of $10 \mathrm{~W} / \mathrm{cm}^{2}$ simulating the filling segment of the cycle for the remaining $10 \mathrm{~ms}$, for a time average total heat flux of $90 \mathrm{~W} / \mathrm{cm}^{2}$. Due to the low thermal conductivity of the ceramic top coat, the temperature of the surface increased, but the depth of the fluctuating temperature decreased by one third, resulting in the decrease of the magnitude of the hoop stresses and the stress ranges. Furthermore, as the frequency of the pulsed heat flux increased the depth of the fluctuating temperature decreased, as well as the stress ranges, although the applied time average heat flux was maintained at $90 \mathrm{~W} / \mathrm{cm}^{2}$. The effect of the increasing frequency was confirmed with experimental studies on a $0.381 \mathrm{~mm}$ YSZ top coat on a Nickel base-alloy, showing a decrease in the apparent thermal conductivity of the top coat with time for a $50 \mathrm{~Hz}$ pulsed heat flux. At $100 \mathrm{~Hz}$, no decrease in the apparent coating thermal conductivity was observed, but a slight increase noticed. Micrographs of the coating tested at $50 \mathrm{~Hz}$ revealed a network of arrays of multi-level microcraks causing the observed reduction in the calculated apparent coating thermal conductivity. Finally, a calibration of the changes of the apparent coating thermal conductivity with various cracking morphologies was established to be used as a coating health monitoring technique for damaged ceramic coating systems. The calibration was used to determine the crack growth rate in a $0.254 \mathrm{~mm}$ thick low conductivity coating, $\mathrm{ZrO}_{2}-\mathrm{Y}_{2} \mathrm{O}_{3}-\mathrm{Gd}_{2} \mathrm{O}_{3}-\mathrm{Yb}_{2} \mathrm{O}_{3}$ (ref. 15), at $20 \mathrm{~Hz}$ for a time average heat flux of $68 \mathrm{~W} / \mathrm{cm}^{2}$ providing an estimate of the normalized crack length of 0.05 at a rate 0.0003 per hour, assuming arrays of multilevel cracking morphology. 


\section{References}

1. Eidelman, S., Grossmann, W. and Lottati, I., "Review of propulsion applications and numerical simulations of the pulsed detonation engine concept," J. Propuls. 7, 1991, pp. 857-865.

2. Bussing, T.R.A. and Pappas, G., "An introduction to pulse detonation engines," in The 32nd Aerospace Sciences Meeting and Exhibit, Indianapolis, IN, AIAA-1994-0263, Jan. 10-13, 1994.

3. Bussing, T.R.A., Hinkey, J.B., and Kaye, L., "Pulse detonation engine preliminary design considerations," in The 30th AIAA/ASME/SAE/ASEE Joint Propulsion Conference, Indianapolis, IN, AIAA-1994-3220, Jun. 2729, 1994.

4. Povinelli, L.A., "Impact of Dissociation and Sensible Heat Release on Pulse Detonation and Gas Turbine Engine Performance," NASA/TM-2001-211080, Jul. 2001.

5. Zhu, D.; Fox, D. S.; and Miller, R. A, "Oxidation- and Creep-Enhanced Fatigue of Haynes 188 Alloy-Oxide Scale System Under Simulated Pulse Detonation Engine Conditions," Ceramic Engineering and Science Proceedings, vol. 23, no. 4, 2002, pp. 547-553.

6. Zhu, D., Fox, D.S., Miller, R.A., Ghosn, L.J., and Kalluri, S., "Effect of Surface Impulsive Thermal Loads on Fatigue Behavior of Constant Volume Propulsion Engine Combustor Materials," Journal of Surface and Coatings Technology, vol. 188-189, Nov.-Dec. 2004, pp. 13-19.

7. Goldstein, R.J., Eckert, E.R.G. and Ramsey, J.W., "Film Cooling Following Injection Through Holes: Adiabatic Wall Temperatures Downstream of a Circular Hole," Journal of Engineering for Power, Transactions of the ASME, vol. 90, no. 4, pp. 384-395, Oct. 1968.

8. Kumud, A., Breisacher, K.J., Ghosn, L.J., Fox, D.S., “ Numerical and Experimental Studies of a Film Cooled Pulsed Detonation Tube", in The 41st AIAA/ASME/SAE/ASEE Joint Propulsion Conference and Exhibit, Tucson, Arizona, AIAA-2004- 3509, Jul. 10-13, 2005.

9. Holden, M.S., Sweet, S.J., "Studies of transpiration cooling with shock interaction in hypersonic flow," Aerospace Ground Testing Conference, 18th, Colorado Springs, CO, AIAA Paper No. 1994-2475, Jun. 20-23, 1994.

10. Miller, R.A., Levine, S.R., Stecura, S., "Thermal barrier coatings for aircraft gas turbines", in the $18^{\text {th }}$ Aerospace Sciences Meeting, Pasadena, California, AIAA-1980-302, Jan. 14-16, 1980.

11. Haynes ${ }^{\circledR} 188$ Alloy Brochure H-3001B, (C) 2000 by Haynes International, Inc., Kokomo, IN.

12. ABAQUS/STANDARD Finite Element Program. Version 6.4, Hibbitt, Karlsson \& Sorensen Inc., Pawtucket, RI.

13. Zhu, D., Choi, S.R. and Miller, R.A., "Development and thermal fatigue testing of ceramic thermal barrier coatings," Surface and Coatings Technology, 188-189, 2004, pp. 146-152.

14. Zhu, D., Choi, S.R., Ghosn, L.J. and Miller, R.A., "Damage Accumulation and Failure of Plasma-Sprayed Thermal Barrier Coatings under Thermal Gradient Cyclic Conditions," The 2005 Cocoa Beach International Conference on Advanced Ceramics and Composites, Cocoa Beach, FL, Jan. 23-28, 2005.

15. Zhu, D. and Miller, R.A., "Development of advanced low conductivity thermal barrier coatings," International Journal of Applied Ceramic Technology, 1, 2004, pp. 86-94. 


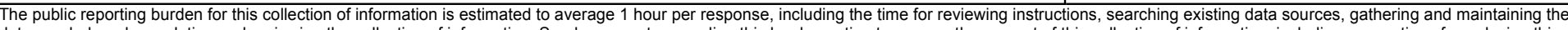

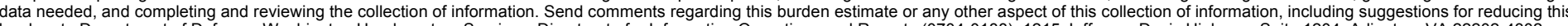

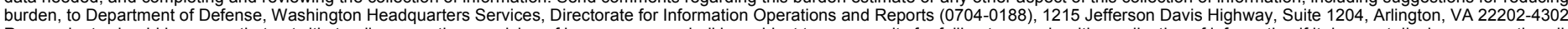

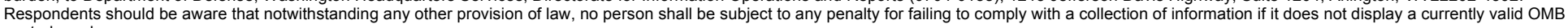
control number.

PLEASE DO NOT RETURN YOUR FORM TO THE ABOVE ADDRESS.

\begin{tabular}{l|l|l}
\hline 1. REPORT DATE (DD-MM-YYYY) & $\begin{array}{l}\text { 2. REPORT TYPE } \\
\text { Technical Memorandum }\end{array}$ & 3. DATES COVERED (FrOm - To)
\end{tabular}

Technical Memorandum

\section{TITLE AND SUBTITLE}

Thermal Barrier and Protective Coatings to Improve the Durability of a Combustor Under a

Pulse Detonation Engine Environment

5a. CONTRACT NUMBER

5b. GRANT NUMBER

5c. PROGRAM ELEMENT NUMBER

6. AUTHOR(S)

Ghosn, Louis, J.; Zhu, Dongming

\section{5d. PROJECT NUMBER}

5e. TASK NUMBER

5f. WORK UNIT NUMBER

WBS 984754.02.07.03.16.03

\section{PERFORMING ORGANIZATION NAME(S) AND ADDRESS(ES)}

National Aeronautics and Space Administration

John H. Glenn Research Center at Lewis Field

Cleveland, Ohio 44135-3191

\section{SPONSORING/MONITORING AGENCY NAME(S) AND ADDRESS(ES)}

National Aeronautics and Space Administration

Washington, DC 20546-0001

and

U.S. Army Research Laboratory

Adelphi, Maryland 20783-1145

\section{DISTRIBUTION/AVAILABILITY STATEMENT}

Unclassified-Unlimited

Subject Categories: 26 and 27

Available electronically at http://gltrs.grc.nasa.gov

This publication is available from the NASA Center for AeroSpace Information, 301-621-0390
8. PERFORMING ORGANIZATION REPORT NUMBER

E-16101

\section{SPONSORING/MONITORS \\ ACRONYM(S)}

\section{SPONSORING/MONITORING}

REPORT NUMBER
2070; ARL-TR-4367

\section{SUPPLEMENTARY NOTES}

\section{ABSTRACT}

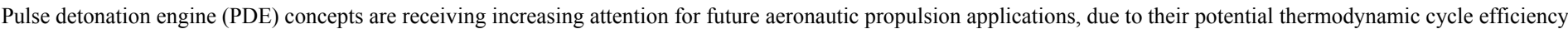

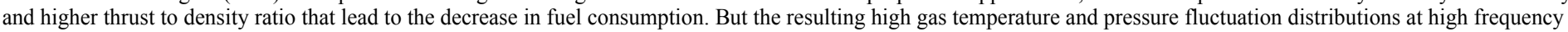

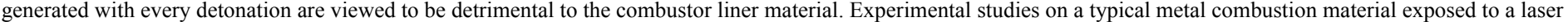

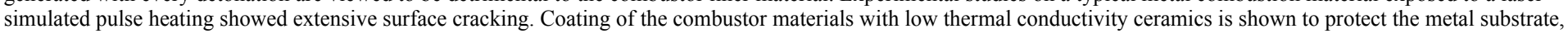

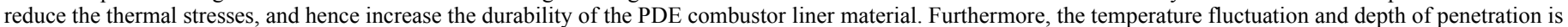

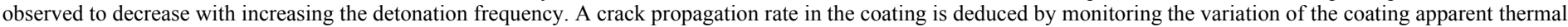
conductivity with time that can be utilized as a health monitoring technique for the coating system under a rapid fluctuating heat flux.

15. SUBJECT TERMS

Pulse detonation engine; Thermal mechanical fatigue; Protective coatings; Crack propagation

\begin{tabular}{|c|c|c|c|}
\hline \multicolumn{3}{|c|}{ 16. SECURITY CLASSIFICATION OF: } & $\begin{array}{l}\text { 17. LIMITATION OF } \\
\text { ABSTRACT }\end{array}$ \\
\hline $\begin{array}{l}\text { a. REPORT } \\
\mathrm{U}\end{array}$ & $\begin{array}{l}\text { b. ABSTRACT } \\
\text { U }\end{array}$ & $\begin{array}{l}\text { c. THIS } \\
\text { PAGE } \\
\text { U }\end{array}$ & UU \\
\hline
\end{tabular}
18. NUMBER
OF PAGES

15 

